P05

A 3D Seismic Chronostratigraphy and Attribute Assessment of Late Jurassic Evaporite Sequences at the Gothnia Basin Margin, Saudi Arabia

S. Wharton* (Saudi Aramco), A.M. Bakhiet (Saudi Aramco) \& P. Lawrence (Saudi Aramco)

For abstract, PTO

No full paper available 


\title{
15055 A 3-D seismic chronostratigraphy and attribute assessment of Late Jurassic evaporite sequences at the Gotnia Basin margin, Saudi Arabia
}

\author{
Stanley R. Wharton (Saudi Aramco <stanley.wharton@aramco.com>), \\ AbdelFattah Bakhiet (Saudi Aramco) and Paul Lawrence (Saudi Aramco)
}

The Jurassic sequences on the Arabian Platform contain widespread carbonate reservoirs, source rocks and seals, which contribute to a world class petroleum system. Since the Triassic Period, the platform was subjected to alternating periods of transgression and regression and differentiation with intra-shelf basins. One key variation in sediment deposition was the formation of evaporite seal beds associated with these intra-shelf basins.

To elucidate the basin depositional history near the flank of the Gotnia Basin margin, a 3-D seismic chronostratigraphic technique and associated attribute assessment were adopted to assess the evaporite distribution during the Late Jurassic. Seismic chronostratigraphy cubes and Wheeler transform models of the chronostratigraphic horizons were generated and interactively assessed for both structural controls to deposition and assessment of transgression and regression, unconformity and hiatus events at the basin margin. The seismic chronostratigraphic model, which represents dense semi-automaticallygenerated horizons placed in chronostratigraphic order, was derived from mapping every sample in the seismic trace. This allowed the interactive assessment of the depositional history of the Late Jurassic basin margin in both time and space, and use of key horizon sets for further attribute assessment.

Use of the extracted 3-D seismic chronostratigraphic horizon sets tied to well log data (gamma-ray, density and sonic), increased the precision in the interpretation of the evaporites and specifically the lateral extent of at least two main salt beds. Using limited well data and key horizon picks in the Arab sequences, selected 3-D seismic volumetric attributes - based mainly on frequency decomposition were generated and utilized for visualization of the salt. The techniques allowed for the definition of the salt beds and the extraction of attributes, from a red, green, blue (RGB) color blend of three main frequencies. Geobody analysis was conducted on each salt-related voxel frequency attribute to further assess the bounding limits of each bed, and the discrimination from surrounding lithologies. Visualizing the individual frequencies showed an overlap of successive salt beds and their regression over time.

The results from the analyses revealed an active basin flank affected by localized structural growth and eustatic changes. Salt beds onlapped the flanks from the north and showed successive retreat during the later Jurassic in time, and towards the Gotnia Basin, spatially. The techniques applied in this study area proved beneficial in accurately defining the limits of the evaporite salt beds, and elucidating the basin history during the Late Jurassic. These findings proved the occurrence of distinct salt layers, each with varying vertical and lateral extents at the Gotnia Basin margin. 